\title{
Serum Hepcidin as a Clinical Prognostic Marker to Discriminate the Outcome of Canine Babesiosis
}

\author{
K. Rajamanickam, V. Leela, K. Loganathasamy, \\ Bhaskaran Ravi Latha, M. Balagangatharathilaga
}

10.18805/IJAR.B-4222

\begin{abstract}
Background: We aimed to identify the prognostic value of hepcidin in discriminating against the survival outcome of canine babesiosis. Methods: Semi-nested polymerase chain reaction was performed to confirm the presence of infection. Existence of oxidative stress and inflammatory response, changes in systemic iron status and hepcidin level were assessed in the study population. Based on the outcome Babesia infected dogs were classified into survivors $(n=18)$ and non-survivors $(n=14)$ of infection. 32 healthy dogs formed the control group.

Conclusion: In non-survivors of infection, serum hepcidin was positively associated with $C$-reactive protein $(P<0.01)$, serum iron $(P<0.01)$, transferrin iron-binding capacity $(P<0.05)$, unsaturated iron-binding capacity $(P<0.01)$, thiobarbituric acid reactive substance $(P<0.05)$ and negatively associated with catalase $(P<0.01)$, zinc $(P<0.01)$ and low haemoglobin density $(P<0.01)$. The prognostic cut-off value of hepcidin in discriminating the survivability of infected dogs was $32.32 \mathrm{ng} / \mathrm{mL}$ with $100.00 \%$ specificity and $92.86 \%$ sensitivity. The area under the curve of hepcidin in discriminating survivability was about 0.984 and Youden's index was 0.928 . Hence, hepcidin can predict the survival outcome of the disease enabling intensive care for animals with a cut-off value of hepcidin more than $32.32 \mathrm{ng} / \mathrm{mL}$.
\end{abstract}

Key words: Babesia infection, Dogs, Inflammation, Oxidative stress, Survivability marker.

\section{INTRODUCTION}

Hepcidin, an antimicrobial peptide synthesized in the liver is a principal regulator of systemic iron homeostasis in mammals, allowing iron adaptation based on the body iron needs (Viatte and Vaulont, 2009). Hepcidin regulates the iron homeostasis by inhibiting the intestinal absorption and the release of iron by macrophages. Expression of hepatic hepcidin hormone depends on the concentration of serum iron, heme (an iron-porphyrin complex), underlying inflammatory process, oxidative stress and hypoxia (Ganz and Nemeth, 2006)

Canine babesiosis, a tick-borne haemoprotozoan disease caused by the apicomplexan parasites of the genus Babesia (Solano-Gallego and Baneth, 2011). Babesia gibsoni and Babesia vogeli are the two important species reported in natural infections in dogs in India (Sarma et al. 2019). Microscopic examination of blood smears remains the gold standard test for diagnosing canine babesiosis and also for differentiating $B$. canis and $B$. gibsoni infection based on the morphometric characteristics (Dantas-Torres and Figueredo, 2006). The current usage of various molecular biology techniques helps in identifying Babesia infection up to species level (Harkirat et al. 2013; Ganguly et al. 2017; Muhammad et al. 2018; Neelam et al. 2018; Maharana et al. 2019). Clinical presentation of affected dogs depends on the species infecting. $B$. vogeli is the least virulent species and it generally causes subclinical infections with a low parasitaemia in adult dogs (Koster et al. 2015), whereas $B$. gibsoni is the most prevalent species with clinical presentations being diverse which range from transient anorexia to severe haemolytic anaemia (Petra et al. 2018).
Department of Veterinary Physiology, Madras Veterinary College, Tamil Nadu Veterinary and Animal Sciences University, Chennai600 007, Tamil Nadu, India.

Corresponding Author: K. Rajamanickam, Department of Veterinary Physiology, Madras Veterinary College, Tamil Nadu Veterinary and Animal Sciences University, Chennai-600 007, Tamil Nadu, India. Email: rajapk92@gmail.com

How to cite this article: Rajamanickam, K., Leela, V., Loganathasamy, K., Latha, B.R., Balagangatharathilagar, M. (2021). Serum Hepcidin as a Clinical Prognostic Marker to Discriminate the Outcome of Canine Babesiosis. Indian Journal of Animal Research. 55(11): 1323-1329. DOI: 10.18805/IJAR.B-4222.

Submitted: $15-06-2020$ Accepted: $28-10-2020$ Online: 29-12-2020

Various studies have identified haematocrit, thrombocyte, lactate, glucose, triglyceride, ALT, phosphate, tumour necrosis factor-alpha, superoxide dismutase, catalase, glutathione peroxidase, malondialdehyde and hormones as prognostic markers in Babesia infection (Koster et al. 2015). Most of these identified markers reflect the ongoing oxidative stress, inflammatory response and metabolic changes. Studies on B. gibsoni reported the existence of changes in serum iron level (Chaudhuri et al. 2008), inflammatory process and acute phase response (Ulutas et al. 2005) and oxidative stress (Murase et al. 1996) in infected dogs and all these factors were also related to the severity of the disease. Since these changes reflect the involvement of multiple organs and they can act as stimuli for hepcidin expression, we hypothesized that there exists a relationship between serum hepcidin level and the severity of the disease. To test this hypothesis, the objectives of the 
Serum Hepcidin as a Clinical Prognostic Marker to Discriminate the Outcome of Canine Babesiosis

current study were to assess the association of serum hepcidin level with oxidative stress, inflammatory response, systemic iron status in dogs naturally infected with babesiosis and also to identify the prognostic value of hepcidin in discriminating the survivability of the affected animals.

\section{MATERIALS AND METHODS}

\section{Experimental animals}

The study was conducted after the approval of the Institutional Animal Ethical and Research Committee (No.318/VPY/MVC/PG Edn./2017). Thirty-two client-owned dogs (22 males and 10 females) irrespective of sex and breed, brought to the Madras Veterinary College Teaching Hospital with clinical signs commensurate with babesiosis like pyrexia, pale and congested mucous membrane, ecchymosis, petechial haemorrhages, melena, haematuria and lymphadenopathy were screened for infection by the semi-nested PCR after getting consent from the owners for the inclusion of their dogs in the study and confirmed to have Babesia infection. The age ranged from 12 to 96 months (median $=54$ months). There were 4 German shepherds, 12 Labrador retrievers, 10 mixed breeds, 2 Spitz's, 2 Dobermans and 2 Great danes. The weight ranged from 18 to $52 \mathrm{~kg}$ (median = $35 \mathrm{~kg}$ ). All the infected dogs were followed up during the treatment period for their survivability and they were classified into survivors $(n=18)$ and non-survivors $(n=14)$ of infection. The control group included 32 healthy, client-owned dogs presented for a routine general health check-up. Clinical examination, peripheral blood smear evaluation, CBC, biochemistry profile, PCR were done in control dogs to rule out infection. Dogs in the control group were age and breed matched with infected groups. B. vogeli infected animals were treated with diminazene aceturate (Berenil@ Vet 7\% RTU; MSD Animal Health) $3.5 \mathrm{mg} / \mathrm{kg}$ IM single dose and dogs with B. gibsoni and dual infection of $B$. vogeli and $B$. gibsoni received clindamycin (Clindapet, Vea Impex, Mumbai, India) $30 \mathrm{mg} /$ $\mathrm{kg}$ PO q12h, diminazene aceturate (Berenil ${ }^{\circledR}$ Vet 7\% RTU; MSD Animal Health) $3.5 \mathrm{mg} / \mathrm{kg}$ IM once on the day of treatment start, imidocarb diproprionate (Imicarb, Vea Impex, Mumbai, India) $6 \mathrm{mg} / \mathrm{kg}$ SC once on the day after diminazene aceturate (Berenil ${ }^{B}$ Vet 7\% RTU; MSD Animal Health) is administered. Also, treatment for the complications was applied at the discretion of the clinician.

\section{Sample collection}

All the blood samples were collected on the first day of admission to the hospital before treatment and they were used immediately for analysis. Blood samples were collected aseptically from each dog by venepuncture of the saphenous vein in vacutainers with EDTA as an anticoagulant for DNA isolation to perform PCR and in clot activator tube for isolation of serum and further biochemical analysis.

\section{Screening for Babesia infection}

Molecular detection of Babesia infection was done by using DNA isolated from whole blood of all the animals (QIAamp DNA Mini Kit $\AA$, Qiagen, Hilden, Germany). After assessing the purity and concentration of the extracted DNA, seminested PCR was done for species identification of Babesia infection. Genus and species-specific primers for the PCR study were selected according to Birkenheuer et al. (2003) (Table 1). The primary PCR for identification of the Babesia genus was performed in a $20 \mu \mathrm{l}$ reaction volume containing $10 \mu \mathrm{l}$ of Taq 2x Master Mix RED $1.5 \mathrm{mMmgCl}_{2}$ (Ampliqon, Denmark), $10 \mathrm{pmol}$ each of forward and reverse primers, $2.0 \mu \mathrm{l}$ of template DNA. The amplification program was done in a thermocycler (T100 ${ }^{\mathrm{TM}}$ Thermal Cycler, Bio-Rad, USA) with initial denaturation at $94^{\circ} \mathrm{C}$ for 5 min followed by 35 cycles of denaturation at $94^{\circ} \mathrm{C}$ for $45 \mathrm{~s}$, annealing at $59^{\circ} \mathrm{C}$ for $45 \mathrm{~s}$ and extension at $72^{\circ} \mathrm{C}$ for $45 \mathrm{~s}$ and a final extension at $72^{\circ} \mathrm{C}$ for $5 \mathrm{~min}$.

The amplicons of primary PCR were subjected to secondary PCR for species confirmation. The cyclical condition for the secondary PCR was similar to that of primary PCR except for the annealing temperature $\left(60^{\circ} \mathrm{C}\right.$ for $45 \mathrm{~s}$ ), reaction cycle (30) and $2.0 \mu \mathrm{l}$ amplicon of primary PCR as DNA template. The amplicons were resolved by electrophoresis on $2 \%$ agarose gel stained with ethidium bromide $(0.4 \mu \mathrm{g} / \mathrm{ml})$ using 100 base pair ladder (Thermo Scientific, Lithuania). The results were visualized and captured using a gel imager (Gel Doc ${ }^{T M} \mathrm{XR}^{+}$Molecular imager ${ }^{\circledR}$, Bio-Rad, Bio-Rad Laboratories, India).

\section{Assessment of oxidative stress}

To detect the presence of oxidative stress, the concentration of serum antioxidant enzymes like catalase, glutathione peroxidase 1, superoxide dismutase were measured by solid sandwich immunoassay using the canine-specific ELISA kit

Table 1: Oligonucleotide primers used in the study.

\begin{tabular}{lllllrr}
\hline Primer & $\begin{array}{l}\text { Sequence } \\
\left(5^{\prime}-3^{\prime}\right)\end{array}$ & $\begin{array}{c}\text { Length } \\
(\mathrm{bp})\end{array}$ & $\begin{array}{l}\text { GC } \\
(\%)\end{array}$ & $\begin{array}{l}\text { Tm } \\
\left({ }^{\circ} \mathrm{C}\right)\end{array}$ & $\begin{array}{r}\text { Amplification } \\
\text { product }\end{array}$ & $\begin{array}{r}\text { Accession } \\
\text { number }\end{array}$ \\
\hline B-FP & GTCTTGTAATTGGAATGATGGTGAC & 25 & 40 & 54 & 340 & AF271081 \\
B-RP & ATGCCCCCAACCGTTCCTATTA & 22 & 50 & 55 & & AF271082 \\
BC-FP & TGCGTTGACGGTTTGACC & 18 & 56 & 50 & 198 & AJ009795 \\
BV-FP & GTTCGAGTTTGCCATTCGTT & 20 & 45 & 50 & 192 & AY072925 \\
BR-FP & GCTTGGCGGTTTGTTGC & 17 & 59 & 49 & 197 & L19079 \\
BG-FP & ACTCGGCTACTTGCCTTGTC & 20 & 55 & 54 & 185 & AF175300 \\
\hline
\end{tabular}

(B-FP: Babesia - Forward Primer, B-RP: Babesia - Reverse Primer, BC-FP: Babesia canis- Forward Primer, BV-FP: Babesia vogeliForward Primer, BR-FP: Babesia rossi- Forward Primer, BG-FP: Babesia gibsoni- Forward Primer). 
(Sincere Biotech, Beijing-101300, China). Lipid peroxidation was determined as thiobarbituric acid reactive substance using the canine-specific ELISA kit (Sincere Biotech, Beijing-101300, China). The serum concentration of antioxidant micro minerals like zinc, selenium and copper was estimated by the atomic absorption spectrophotometer (PinnAAcle900H, PerkinElmer Health Science Pvt. Ltd. India). Concentrations of zinc and copper were estimated by air acetylene flame method using a hollow cathode lamp at the wavelength of $213.86 \mathrm{~nm}$ and $324.75 \mathrm{~nm}$ respectively. The concentration of selenium was estimated by the graphite furnace method using an electrodeless discharge lamp at the wavelength of $196.03 \mathrm{~nm}$. Standard concentration (linear plot) of zinc, copper and selenium used in measurements were 0 to $1.5 \mathrm{ppm}, 0$ to $2 \mathrm{ppm}$ and 0 to $80 \mathrm{ppm}$ respectively.

\section{Assessment of acute-phase response and hepcidin concentration}

Serum C-reactive protein concentration was measured by using a commercial C-reactive protein assay kit (Sincere Biotech, Beijing-101300, China). The concentration of serum amyloid $A$ and serum hepcidin were determined with a canine-specific solid sandwich immunoassay (Sincere Biotech, Beijing-101300, China). The final absorbance of samples was measured at $450 \mathrm{~nm}$ (Epoch Microplate Spectrophotometer, BioTek Instruments, Inc., USA).

\section{Assessment of systemic iron status}

Serum iron, TIBC and UIBC were estimated by ferrozine method using the colorimetric kit (Coral clinical systems, Goa, India). Low haemoglobin density, an indicator of functional iron availability was identified by the mathematical sigmoid transformation of mean cell haemoglobin concentration of all the animals using the formula described by Urrechaga (2010).

$$
\mathrm{LHD} \%=100 * \sqrt{ } 1-\left[1 /\left(1+\mathrm{e}^{1.8(30-\mathrm{MCHC})}\right)\right]
$$

\section{Statistical analysis}

Normality of data was assessed by Shapiro-Wilk test. Oneway analysis of variance followed by pair-wise comparisons using the Tukey's test was used to determine the significant variation among control, survivor and non-survivors of infection and also among three different disease groups. Pearson's correlation was performed to assess the association between hepcidin and other parameters. Receiver operating characteristics curve analysis was used to determine the use of hepcidin as a prognostic marker to discriminate the survivability of dogs with canine babesiosis. $\mathrm{P}<0.05$ was considered statistically significant. All analyses were performed using a commercial statistics program (SPSS IBM Version 23 software, IBM Statistics, Armonk, NY, USA).

\section{RESULTS AND DISCUSSION}

Polymerase chain reaction targeting the Babesial 18S rRNA gene yielded 340 bp amplicon in 32 samples which indicated the presence of Babesia infection. Out of 32 positive animals, 8 dogs were positive for $B$. vogeli with a specific band at $192 \mathrm{bp}$, while 12 dogs were positive for $B$. gibsoni with a specific band at $185 \mathrm{bp}$. Mixed infection of $B$. vogeli and $B$. gibsoni was detected in 12 samples. Out of 32 infected dogs, 14 died and 18 dogs survived. Among the 14 non-survivors, 3 dogs had $B$. gibsoni infection and 11 dogs had mixed infection of $B$. gibsoni and $B$. vogeli. Out of 18 survivors, 8 dogs had $B$. vogeli infection, 9 dogs had $B$. gibsoni infection and 1 dog had a mixed infection of both. No mortality was seen in dogs with $B$. vogeli infection while $B$. gibsoni infection resulted in $25 \%$ mortality. However, in animals with mixed infection of both B. gibsoni and B. vogeli $91.6 \%$ mortality was observed, which revealed that a combination of these two species was detrimental to the affected animals.

On comparing the levels of laboratory variables among the different disease groups, catalase $(P<0.05)$, superoxide

Table 2: Results for comparison of variables in three different diseases in the study population (Mean and SEM).

\begin{tabular}{|c|c|c|c|}
\hline Parameters & $\begin{array}{l}\text { B. vogeli } \\
\text { infection }\end{array}$ & $\begin{array}{l}\text { B. gibsoni } \\
\text { infection }\end{array}$ & $\begin{array}{l}\text { Mixed infection of } \\
\text { B. vogeli and B. gibsoni }\end{array}$ \\
\hline 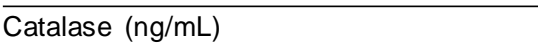 & $6.907 \pm 0.708^{a}$ & $6.186 \pm 0.519^{\mathrm{ab}}$ & $4.953 \pm 0.458^{b}$ \\
\hline Glutathione peroxidase- $1(\mathrm{ng} / \mathrm{mL})$ & $4.159 \pm 0.527^{\mathrm{a}}$ & $4.138 \pm 0.375^{\mathrm{a}}$ & $4.151 \pm 0.433^{\mathrm{a}}$ \\
\hline Superoxide dismutase $(\mathrm{ng} / \mathrm{mL})$ & $6.953 \pm 0.886^{\mathrm{a}}$ & $4.515 \pm 0.572^{b}$ & $4.198 \pm 0.392^{b}$ \\
\hline TBARS $(\mathrm{ng} / \mathrm{mL})$ & $16.435 \pm 1.995^{\mathrm{a}}$ & $26.013 \pm 5.489^{\mathrm{ab}}$ & $31.025 \pm 1.620^{\mathrm{b}}$ \\
\hline Serum amyloid $A(n g / m L)$ & $26.376 \pm 3.034^{\mathrm{a}}$ & $28.087 \pm 2.616^{\mathrm{a}}$ & $26.785 \pm 1.96^{a}$ \\
\hline C-reactive protein & $62.288 \pm 8.397^{a}$ & $77.583 \pm 7.775^{\mathrm{a}}$ & $123.409 \pm 7.242^{\mathrm{b}}$ \\
\hline Zinc ( $\mu$ mole/L) & $19.218 \pm 0.071^{\mathrm{a}}$ & $17.985 \pm 0.808 a^{b}$ & $14.915 \pm 1.001^{b}$ \\
\hline Copper $(\mu \mathrm{mole} / \mathrm{L})$ & $7.502 \pm 0.840^{\mathrm{a}}$ & $7.851 \pm 0.705^{\mathrm{a}}$ & $7.121 \pm 0.760^{\mathrm{a}}$ \\
\hline Selenium ( $\mu$ mole/L) & $7.224 \pm 0.692^{\mathrm{a}}$ & $7.235 \pm 0.310^{\mathrm{a}}$ & $6.738 \pm 0.343^{a}$ \\
\hline Iron $(\mu \mathrm{g} / \mathrm{dL})$ & $49.710 \pm 7.086^{\mathrm{a}}$ & $28.176 \pm 3.210^{\mathrm{b}}$ & $14.430 \pm 1.917^{\mathrm{b}}$ \\
\hline Low hemoglobin density (\%) & $9.475 \pm 1.920^{\mathrm{a}}$ & $21.233 \pm 5.170^{\mathrm{ab}}$ & $39.045 \pm 5.749^{b}$ \\
\hline Transferrin iron-binding capacity $(\mu \mathrm{g} / \mathrm{dL})$ & $232.151 \pm 21.976^{\mathrm{a}}$ & $263.112 \pm 26.375^{\mathrm{a}}$ & $349.565 \pm 21.438^{b}$ \\
\hline Unsaturated iron-binding capacity $(\mu \mathrm{g} / \mathrm{dL})$ & $200.610 \pm 20.391^{\mathrm{a}}$ & $216.011 \pm 29.248^{\mathrm{a}}$ & $333.831 \pm 22.067^{\mathrm{b}}$ \\
\hline Hepcidin $(\mathrm{ng} / \mathrm{mL})$ & $21.763 \pm 2.354^{\mathrm{a}}$ & $26.718 \pm 3.211^{\mathrm{a}}$ & $43.613 \pm 3.011^{\mathrm{b}}$ \\
\hline
\end{tabular}

Note: (a c) values with no superscripts in common are significantly different from one another. 
dismutase $(\mathrm{P}<0.05)$, thiobarbituric acid reactive substance $(P<0.05)$, C-reactive protein $(P<0.01)$, zinc $(P<0.05)$, iron $(P<0.01)$, LHD $(P<0.01)$, TIBC $(P<0.01)$, UIBC $(P<0.01)$ and hepcidin $(P<0.01)$ were significantly altered (Table 2$)$. Dogs with mixed infection of $B$. gibsoni and $B$. vogeli had more pronounced variations in the parameters under study when compared to other disease groups which attributed to the virulence of both species (Solano-Gallego and Baneth, 2011).

Serum hepcidin concentration was found to be significantly higher $(P<0.01)$ in non-survivors than in survivors and control groups (Fig 1). Correlation between serum hepcidin level and various parameters of oxidative stress, acute phase response and systemic iron status in non-survivors revealed that hepcidin was positively associated with $\mathrm{C}$-reactive protein $(P<0.01)$, serum iron $(P<0.01)$, TIBC $(P<0.05)$, UIBC $(P<0.01)$, thiobarbituric acid reactive substance $(P<0.05)$ and negatively associated with catalase $(P<0.01)$, zinc $(P<0.01)$ and LHD $(P<0.01)$ (Table 3$)$. The positive association of oxidative stress markers with hepcidin occurred as a result of oxidative stress-induced hepcidin synthesis by activation of transcription factor cAMPresponse-element-binding-protein- $\mathrm{H}$ or by the stressinducible transcription factors CCAAT-enhancer-binding protein $(\mathrm{C} / \mathrm{EBPa})$ and $\mathrm{C} / \mathrm{EBP}$-homologous protein (Oliveira et al. 2009).

Concentrations of all the three antioxidant enzymes were reduced $(P<0.01)$ in both non-survivors and survivors of infection when compared to the control group, but only catalase concentration was significantly reduced $(P<0.01)$ in non-survivors than survivors of infection (Fig $2 a, 2 b, 2 c$ ). Lipid peroxidation was found to be significantly higher in non-survivors of infection than survivors $(P<0.01)$ and control groups $(P<0.01)$ (Fig $2 d)$. Among the antioxidant micro minerals, only serum zinc concentration was significantly reduced $(P<0.05)$ in non-survivors when compared to the survivors and control groups (Fig 3a). Previous studies also confirmed the presence of oxidative stress in canine babesiosis infection (Murase et al. 1996; Chaudhuri et al. 2008).

No significant change was observed in Serum amyloid A concentration among the three different groups (Fig 4a). Non-survivors of infection were found to have significantly increased C-reactive protein concentration $(\mathrm{P}<0.01)$ (Fig $4 \mathrm{~b}$ ) and it is also positively associated with serum hepcidin level. Previous reports on changes in acute phase response during babesiosis indicate an increase in C-reactive protein is associated with the severity and complications of the disease (Matijatko et al. 2002; Ulutas et al. 2005). During canine babesiosis, pro-inflammatory cytokines like interleukin-6 are produced as a host defence mechanism against the inflammatory reaction of the organism (Goddard et al. 2016), which can stimulate the hepcidin synthesis through activation of Janus Kinase /signal transducer and

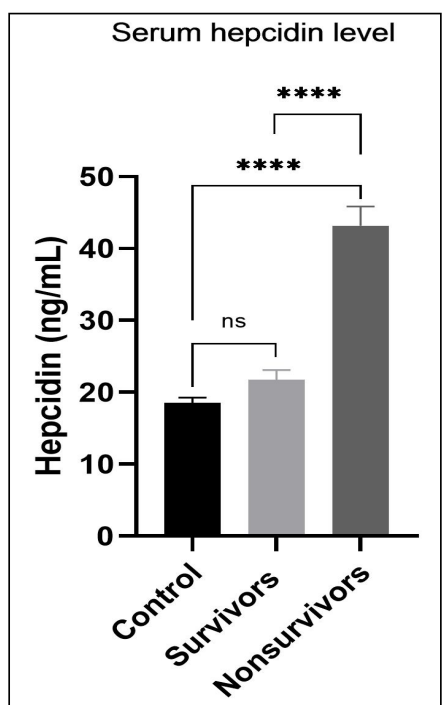

Fig 1: Serum hepcidin level of control dogs, survivors and nonsurvivors of babesiosis. $\left(^{* * *}\right.$ - differs significantly at $\mathrm{P}<0.0001$; ns- no significant difference; Mean and SEM).

Table 3: Correlation of hepcidin with other variables of non-survivors of canine babesiosis.

\begin{tabular}{lcc}
\hline Parameters & & Hepcidin \\
\cline { 2 - 3 } & Pearson correlation coefficient & P-value \\
\hline Catalase $(\mathrm{ng} / \mathrm{mL})$ & -0.480 & 0.005 \\
Glutathione peroxidase $(\mathrm{ng} / \mathrm{mL})$ & 0.204 & 0.264 \\
Superoxide dismutase $(\mathrm{ng} / \mathrm{mL})$ & 0.069 & 0.708 \\
Thiobarbituric acid reactive substance $(\mathrm{ng} / \mathrm{mL})$ & 0.339 & 0.058 \\
Serum amyloid A $(\mathrm{ng} / \mathrm{mL})$ & 0.058 & 0.753 \\
C-reactive protein & 0.666 & 0.000 \\
Zinc $(\mu$ mole/L) & -0.482 & 0.005 \\
Copper $(\mu$ mole/L) & -0.162 & 0.375 \\
Selenium $(\mu$ mole/L) & 0.069 & 0.707 \\
Iron $(\mu \mathrm{g} / \mathrm{dL})$ & 0.514 & 0.003 \\
Low hemoglobin density $(\%)$ & -0.523 & 0.002 \\
Transferrin iron-binding capacity $(\mu \mathrm{g} / \mathrm{dL})$ & 0.387 & 0.029 \\
Unsaturated iron-binding capacity $(\mu \mathrm{g} / \mathrm{dL})$ & 0.506 & 0.003 \\
\hline
\end{tabular}




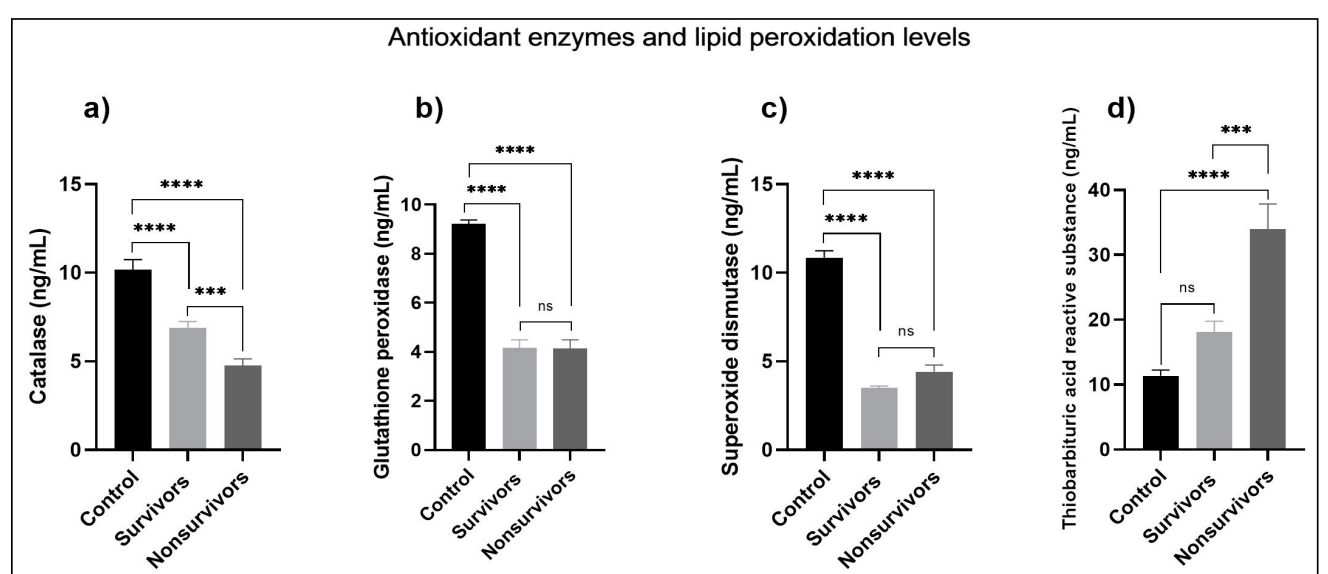

Fig 2: Antioxidant enzyme levels and lipid peroxidation of control dogs, survivors and non-survivors of babesiosis.

$\left({ }^{* * * *}\right.$ - differs significantly at $\mathrm{P}<0.0001$; ${ }^{* * *}$ - differs significantly at $\mathrm{P}<0.001$; ns - no significant difference; Mean and SEM).

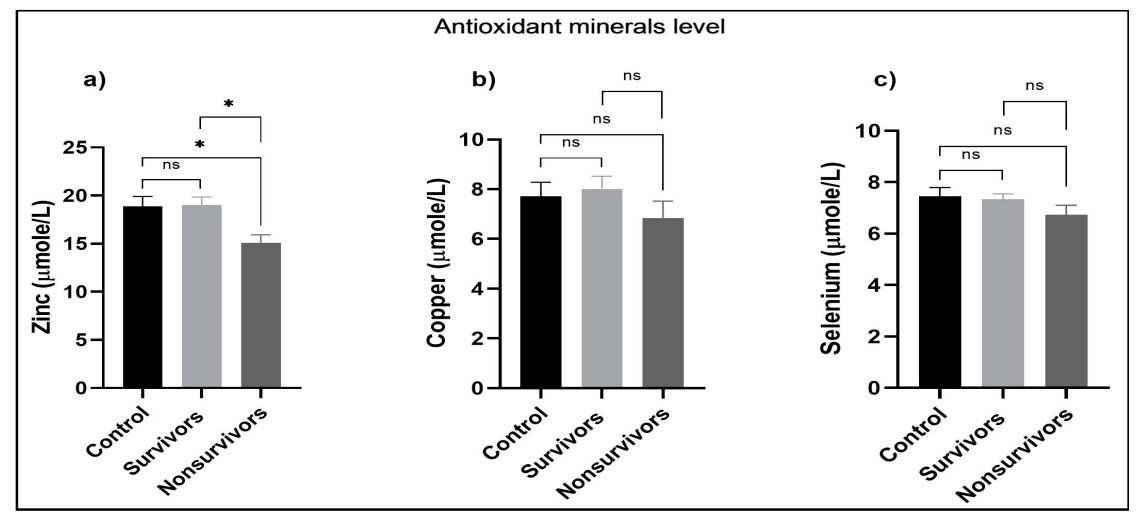

Fig 3: Antioxidant minerals levels of control dogs, survivors and non-survivors of babesiosis. $\left({ }^{*}\right.$ - differs significantly at $\mathrm{P}<0.05$; ns - no significant difference; Mean and SEM).

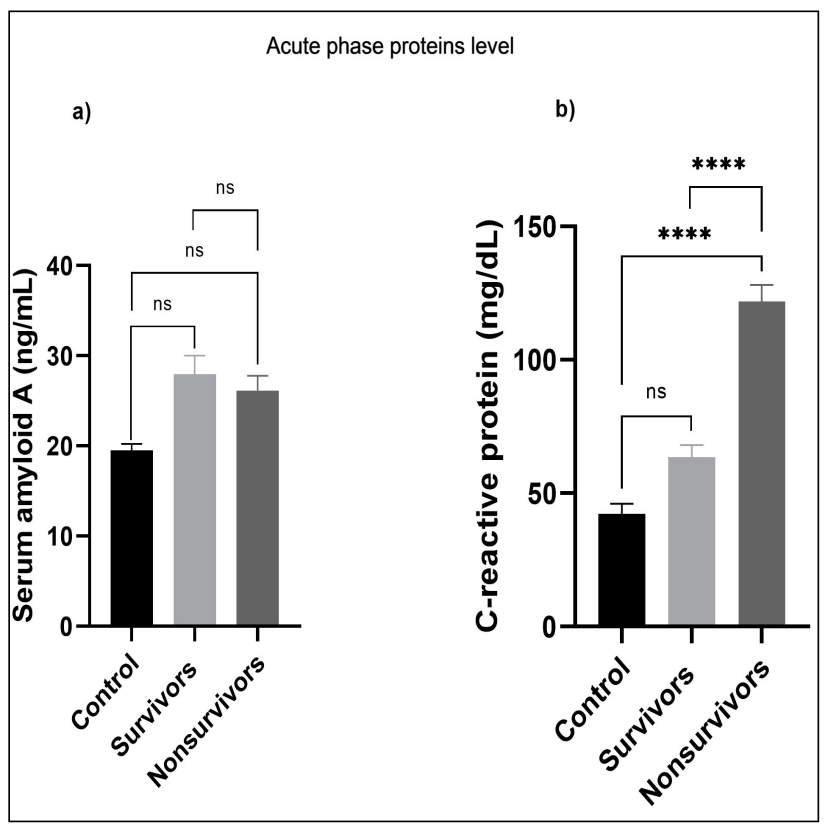

Fig 4: Acute-phase proteins levels of control dogs, survivors and non-survivors of babesiosis (**** differs significantly at $\mathrm{P}<0.0001$; ns - no significant difference; Mean and SEM). activator of a transcription-3 signalling pathway (Wrighting and Andrews, 2006).

Comparison of serum iron level among the three different groups revealed a significant reduction in both survivors $(P<0.01)$ and non-survivors $(P<0.01)$ of infection than control dogs and it also revealed that non-survivors of infection had significantly $(P<0.05)$ reduced serum iron level than survivors of infection (Fig $5 \mathrm{a}$ ). Non-survivors of infection had significantly elevated LHD and TIBC than survivors (LHD - $P<0.01$; TIBC $-P<0.01$ ) and control dogs (LHD - $\mathrm{P}<0.01$; TIBC - $\mathrm{P}<0.01$ ) (Fig 5b, 5c). Unsaturated iron binding capacity was significantly increased in both survivors $(P<0.01)$ and non-survivors $(P<0.01)$ of infection than control dogs (Fig $5 \mathrm{~d}$ ). Non-survivors of infection had significantly reduced serum iron $(P<0.05)$ and increased LHD $(P<0.01)$, TIBC $(P<0.01)$ than survivors (Fig 5$)$. This confirms there exists an association among systemic ironrelated parameters and serum hepcidin levels in nonsurvivors of infection. In canine babesiosis, the serum iron level is not a static one and its concentration differs according to the severity of anaemia (Lobetti, 2003) and also increased intravascular erythrocatheresis due to parasitaemia will elevate the circulating heme concentration (Conrad et al. 1991). Heme is a potent pro-inflammatory 


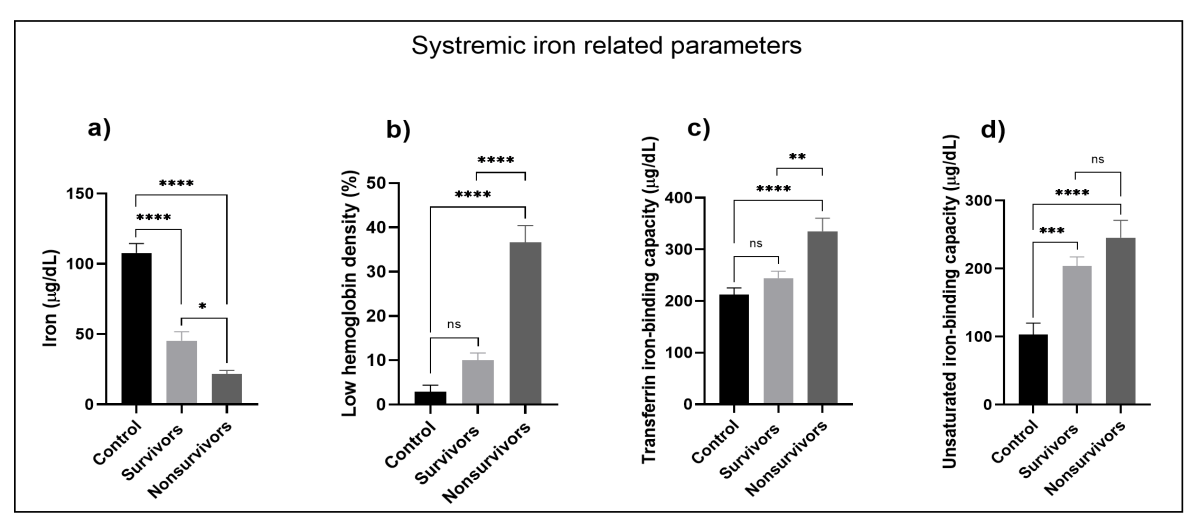

Fig 5: Iron related parameters of control dogs, survivors and non-survivors of babesiosis.

$\left({ }^{* * * *}\right.$ - differs significantly at $\mathrm{P}<0.0001$; ${ }^{* * *}$ - differs significantly at $\mathrm{P}<0.001$; ${ }^{* *}$ - differs significantly at $\mathrm{P}<0.01$; ${ }^{*}$ - differs significantly at $\mathrm{P}<0.05$; ns - no significant difference; Mean and SEM).

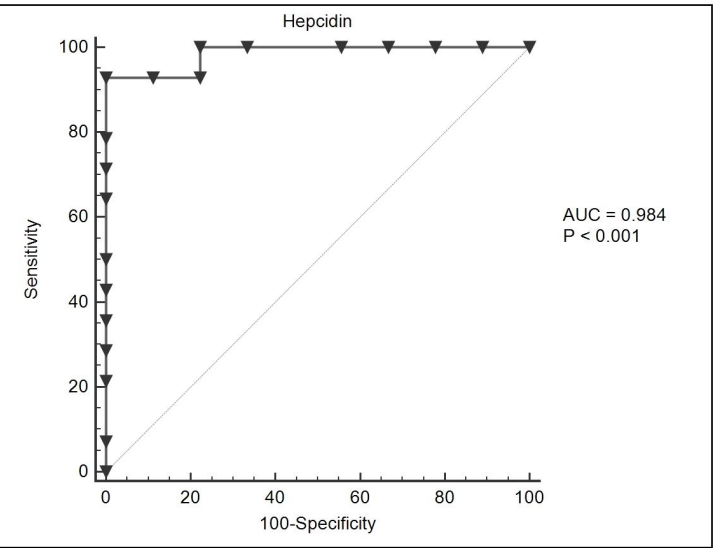

Fig 6: Receiver operating characteristics curve analysis of serum hepcidin (Receiver operating characteristics curve of hepcidin lies toward true positive (sensitivity) axis suggesting its high disease discriminate capacity and also higher area under curve value indicates better accuracy of the test).

iron-containing molecule, which binds to toll-like receptor 4 and mediates the up-regulation of hepcidin expression through extracellular signal-regulated kinases pathway (Tangudu and Spasic, 2017).

The receiver operating characteristics curve analysis identified the prognostic cut-off value of hepcidin as $32.32 \mathrm{ng} / \mathrm{mL}$ with $100.00 \%$ specificity and $92.86 \%$ sensitivity. The area under the curve of hepcidin was about 0.984 at the confidence interval of $86.30 \%$ and $100.00 \%$ $(\mathrm{P}<0.01)$ and the Youden's index was 0.928 (Fig 6). It suggests that infected animals with a cut-off value above this will succumb to the disease. The advantage of using hepcidin as an indicator of prognosis in canine babesiosis is that as a single clinical variable it explains the alteration in systemic iron status, inflammatory process and oxidative stress. Previously identified prognostic markers of canine babesiosis like thrombocyte, lactate, glucose, triglyceride and phosphate will explain the prevailing pathogenicity when clinically assessed in combination, not as a single variable (Koster et al. 2015). This is the first study to explain the use of hepcidin as a prognostic marker in canine babesiosis and the limitations are small study population.

\section{CONCLUSION}

In the current study, data reflects the complexity in the pathogenesis of the disease and how the serum hepcidin was related to the severity of the disease. Hepcidin level of non- survivors of infection was found to be associated with the existing oxidative stress, inflammation, changes in iron level and also it was identified that serum hepcidin has a survivability cut-off value of $32.32 \mathrm{ng} / \mathrm{mL}$ in prognosticating the outcome of canine babesiosis.

\section{ACKNOWLEDGEMENT}

The authors acknowledge the Tamil Nadu Veterinary and Animal Sciences University for funding this research work.

\section{REFERENCES}

Birkenheuer, A.J., Levy, M.G. and Breitschwerdt, E.B. (2003). Development and evaluation of semi-nested PCR for detection and differentiation of Babesia gibsoni (Asian genotype) and $B$. canis DNA in canine blood samples. Journal of Clinical Microbiology. 41: 4172-4177.

Chaudhuri, S., Varshney, J.P. and Patra, R.C. (2008). Erythrocytic antioxidant defense, lipid peroxide level and blood iron, zinc and copper concentrations in dogs naturally infected with Babesia gibsoni. Research in Veterinary Science. 85: 120-124.

Conrad, P., Thomford, J., Yamane, I., Whiting, J., Bosma, L., Uno, T., Holshuh, H.J. and Shelly, S. (1991). Hemolytic anemia is caused by Babesia gibsoni infection in a dog. Journal of American Veterinary Medical Association. 199: 601-605

Dantas-Torres, F. and Figueredo, L.A. (2006). Canine babesiosis: a Brazilian perspective. Veterinary Parasitology. 141: 197203.

Ganguly, A., Bisla, R.S., Ganguly, I., Singh, H., Bhanot, V. and Chaudhri, S.S. (2017). Direct blood PCR detection of Babesia bigemina and its effect on hematological and biochemical profile in crossbred cattle of eastern Haryana. Indian Journal of Animal Research. 51: 141-145. 
Ganz, T. and Nemeth, E. (2006). Iron imports. IV. Hepcidin and regulation of body iron metabolism. American Journal of Physiology. 290: G199-G203

Goddard, A., Leisewitz, A.L., Kjelgaard- Hansen, M., Kristensen, A.T. and Schoeman, J.P. (2016). Excessive pro-inflammatory serum cytokine concentrations in virulent canine babesiosis. PLoS ONE. 11: e0150113.

Harkirat, S., Jyoti, Haque, M., Singh, N.K. and Rath, S.S. (2013). PCR based detection of subclinical bovine babesiosis in Punjab. Indian Journal Animal Research. 47: 543-546.

Koster, L., Lobetti, R.G. and Kelly, P. (2015). Canine babesiosis: A perspective on clinical complications, biomarkers and treatment. Veterinary Medicine: Research and Reports. 6: $119-128$

Lobetti, R.G. (2003). Hematological Changes in TBDs. Proceedings in $21^{\text {st }}$ ACVIM Forum, Charlotte, NC, 554-556.

Maharana, B.R., Kumar, B., Joseph, J.P. and Patbandha, T.K. (2019). A comparative analysis of microscopy and PCR based detection methods for Babesia and Trypanosoma infecting bovines and assessment of risk factors. Indian Journal of Animal Research. 53: 382-387.

Matijatko, V., Kucer, N., Rafaj, R.B., Forsek, J., Kis, I., Potocnjak, D., Razdorov, G. and Mrljak, V. (2002). CRP Concentration in Dogs with Uncomplicated Babesiosis. Proceedings of $3^{\text {rd }}$ European Colloquium on Acute Phase Proteins, Doorn, Netherlands.

Muhammad, A.S., Raheela, A., Muhammad, L., Muhammad, I.R., Haroon, A., Wasim, S., Fareeha, A., Saher, I., Shahid, H.F. and Uzma, F.D. (2018). First report on optimization of loop-mediated isothermal amplification (LAMP) for the diagnosis of Babesia felis. Indian Journal of Animal Research. 52: 401-404.

Murase, T., Ueda, T., Yamato, O., Tajima, M. and Maede, Y. (1996). Oxidative damage and enhanced erythrophagocytosis in canine erythrocytes infected with Babesia gibsoni. Journal of Veterinary Medical Science. 58: 259-261.
Neelam, K., Debabrata, M., Karam, P.S. and Rashmi, R.M. (2018). Comparative evaluation of different diagnostic tests for B. gibsoni in dogs. Indian Journal of Animal Research. 52: $1642-1648$.

Oliveira, S.J., Pinto, J.P., Picarote, G., Costa, V.M., Carvalho, F., Rangel, M., de Sousa, M. and de Almeida, S.F. (2009). ER stress-inducible factor $\mathrm{CHOP}$ affects the expression of hepcidin by modulating C/EBP alpha activity. PLoS ONE. 4: e6618

Petra, B., Josipa, K., Renata, B.R. and Valdimir, M. (2018). Canine babesiosis: Where do we stand? Acta Vet-Beograd. 68: 127-160.

Sarma, K., Nachum-Biala, Y., Kumar, M. and Baneth, G. (2019). Molecular investigation of vector-borne parasitic infections in dogs in Northeast India. Parasite and Vectors. 12: 122.

Solano-Gallego, L. and Baneth, G. (2011). Babesiosis in dogs and cats expanding parasitological and clinical spectra. Journal of Veterinary Parasitology. 181: 48-60.

Tangudu, N.K. and Spasic, M.V. (2017). Heme activates macrophage hepcidin expression via toll-like receptor 4 and extracellular signal-regulated kinases signaling pathway. Clinical Pharmacology and Biopharmaceutics. 6: 166.

Ulutas, B., Bayramli, G., Ulutas, P.A. and Karagenc, T. (2005). Serum concentration of some acute phase proteins in naturally occurring canine babesiosis: A preliminary study. Veterinary Clinical Pathology. 34: 144-147.

Urrechaga, E. (2010). The new mature red cell parameter, low hemoglobin density of the Beckman-Coulter LH750: Clinical utility in the diagnosis of iron deficiency. International Journal of Laboratory Hematology. 32: 144-150.

Viatte, L. and Vaulont, S. (2009). Hepcidin, the iron watcher. Biochimie. 91: 1223-1228

Wrighting, D.M. and Andrews, N.C. (2006). Interleukin-6 induces hepcidin expression through STAT3. Blood. 108: 32043209. 